\title{
Effects of doping alumina on the electrical and sintering performances of yttrium-stabilized-zirconia
}

Fangyong Yu $\mathrm{u}^{\mathrm{a}}$, Jie Xiao ${ }^{\mathrm{b}, \mathrm{c}}$, Libin Lei ${ }^{\mathrm{b}}$, Weizi Cai ${ }^{\mathrm{b}}$, Yapeng Zhang ${ }^{\mathrm{a}}$, Jiang Liu ${ }^{\mathrm{a}}{ }^{\mathrm{b} *}$, Meilin

$$
\operatorname{Liu}^{\mathrm{a}, \mathrm{d}}
$$

${ }^{a}$ New Energy Research Institute, School of Environment and Energy, South China University of Technology, Guangzhou 510006, P. R. China

${ }^{\mathrm{b}}$ School of Chemistry and Chemical Engineering, South China University of Technology, Guangzhou 510641, P.R. China

${ }^{c}$ Faculty of Metallurgical and Energy Engineering, Kunming University of Science and Technology,

$$
\text { Kunming 650093, China }
$$

${ }^{\mathrm{d}}$ School of Materials Science and Engineering, Georgia Institute of Technology, 771Ferst Drive, Atlanta,

$$
\text { GA 30332-0245, USA }
$$

\begin{abstract}
:
The effects of doping amount and particle size of alumina on the sintering behavior and electrical performance of $8 \mathrm{~mol} \%$ yttria-stabilized zirconia (YSZ) are investigated through microstructure and impedance spectroscopy analysis. Initial results show that a proper amount of $\mathrm{Al}_{2} \mathrm{O}_{3}$ doping can effectively improve the sintering behavior and the electrical performance
\end{abstract}

* Corresponding author: Tel: +86202223 6168; fax: +862022236168.

E-mail address: jiangliu@scut.edu.cn 
of YSZ, and the optimum doping amount varies with the particle size of $\mathrm{Al}_{2} \mathrm{O}_{3}$. When a raw $\mathrm{Al}_{2} \mathrm{O}_{3}$ powder (modal particle size: $0.28 \mathrm{~m}$ ) is used as dopant, the optimal doping amount for electrical and sintering improvement is 0.7 wt.\% and $3 \mathrm{wt} . \%$, respectively, while that with $1400{ }^{\circ} \mathrm{C}$-calcined- $\mathrm{Al}_{2} \mathrm{O}_{3}(0.45 \mathrm{~m}), 1 \mathrm{wt} . \%$ and $4 \mathrm{wt} \%$. A concept of space distribution distance of the doping particles is introduced to interpret the improvement effect.

Keywords: SOFC; YSZ; alumina; particle size

\section{Introduction}

The solid oxide fuel cell (SOFC) is attracting increasing interests due to its advantages such as high efficiency in converting chemical energy of fuels to electrical power, zero or low emissions, fuel flexibility, and all-solid-state configuration, etc. [1-5]. As one of the key components of a SOFC, the electrolyte is required to possess high ionic conductivity, good stability in both oxidizing and reducing atmospheres, chemical and thermal compatibility with the electrodes, impermeability to gases, high strength and toughness, easy fabrication, low cost and so on. Currently, yttria-stabilized zirconia (YSZ) is the most commonly used electrolyte for SOFCs because it meets most of the requirements. However, its application in SOFCs is often hindered by high sintering temperature and low mechanical strength. To solve these problems, small amount of sintering aids, e.g., $\mathrm{Fe}_{2} \mathrm{O}_{3}, \mathrm{Bi}_{2} \mathrm{O}_{3}$, and $\mathrm{Al}_{2} \mathrm{O}_{3}$, have been added to YSZ, to lower the sintering temperature as well as to enhance the mechanical strength. Several studies have been reported regarding to the effects of alumina addition on the sintering $[6,7]$, electrical $[8,9]$, microstructure [10] and mechanical properties [11] of YSZ. The reported optimal doping amount of alumina from different sources varies because it 
is determined by some factors such as the nature of starting materials, including particle size, impurity content, and processing conditions. Miyayama et. al. [12] have studied the electrical properties of YSZ doped with $0-1.0 \mathrm{~mol} \%$ alumina, and found that the electrical conductivity increases with alumina concentration when the dopant is less than $0.6 \mathrm{~mol} \%$, but decreases when it is above $0.6 \mathrm{~mol} \%$. Ji et. al. [13] found that doping 4 wt.\% alumina to YSZ could significantly improve its sinterability. The SOFC with the 4 wt.\% alumina-doped YSZ electrolyte also performed the best compared to those with other doping amount or pure YSZ electrolyte. In our previous work, the effects of alumina doping amount and sintering procedure on the sinterability and electrical property of YSZ, as the electrolyte of SOFCs, were investigated [14]. The results showed that doping 1 wt.\% alumina into YSZ could reduce the sintering temperature from $1400{ }^{\circ} \mathrm{C}$ to $1300{ }^{\circ} \mathrm{C}$, and a single cell with $1 \mathrm{wt} . \%$ alumina-doped YSZ electrolyte sintered at $1300{ }^{\circ} \mathrm{C}$ revealed higher output $\left(684 \mathrm{~mW} \mathrm{~cm}{ }^{-2}\right)$ than that with pure YSZ electrolyte sintered at $1400{ }^{\circ} \mathrm{C}$ did $\left(429 \mathrm{~mW} \mathrm{~cm}{ }^{-2}\right)$. It has been pointed out that the sinterability improvement is caused by a proper segregation of alumina particles on the grain boundaries of YSZ that may enhance the mobility of the boundaries [9, 13-14]. Thus, it should be reasonable to presume that smaller amount (by weight or volume) of alumina is needed to get the sinterability improvement if finer alumina particles are applied for the doping. However, the effect of the particle size of doping alumina on the properties of the corresponding doped YSZ has not been well explored. The only work, to our best knowledge, is reported by Mori et. al. [15]. They found that the particle size of alumina affected the particle distribution in the sintered composites but had little effect on the strength.

In this paper, we report our research on the effects of the properties of doping alumina, 
including particle size, adjusted by pre-calcining, and doping amount, on the sintering and electrical performances of YSZ. The perspective of the contribution of grain boundary and bulk conductivity to the total ionic conductivity are presented and analyzed. The performances of electrolyte-supported SOFCs with YSZ of the optimal amount of alumina addition and pure YSZ are investigated as well.

\section{Experimental}

\subsection{Preparation of electrolyte}

Raw alumina powder $\left(\mathrm{Al}_{2} \mathrm{O}_{3}\right.$, Xinfumeng, China, $99.99 \%$ purity $), 8 \mathrm{~mol} \%$ yttria-stabilized zirconia (YSZ, Tosoh, Japan, $99.99 \%$ purity), and the $\mathrm{Al}_{2} \mathrm{O}_{3}$ powder calcined at $1400{ }^{\circ} \mathrm{C}$ for $2 \mathrm{~h}\left(1400{ }^{\circ} \mathrm{C}-\mathrm{Al}_{2} \mathrm{O}_{3}\right)$ were used as starting materials. Two sets of $\mathrm{YSZ} / \mathrm{Al}_{2} \mathrm{O}_{3}$ composite samples with $0.4,0.7,1,3,4,5,7$ and 9 wt.\% (regarding to the amount of YSZ) of $\mathrm{Al}_{2} \mathrm{O}_{3}$ addition were respectively prepared, one with the raw $\mathrm{Al}_{2} \mathrm{O}_{3}$ powder and the other with the powder calcined at $1400{ }^{\circ} \mathrm{C}$. The $\mathrm{YSZ}$ and $\mathrm{Al}_{2} \mathrm{O}_{3}$ powders, with a certain weight percentage as mentioned above, were mixed with ethanol and ball milled for $2 \mathrm{~h}$, using zirconia balls as milling media (weight ratio of ball to powder is 2:1). The mixture was subsequently dried in air for $12 \mathrm{~h}$, and then ground by agate mortar and pestle. Then, the mixed powder was pressed into pellets (the weight of each pellet was $0.3 \mathrm{~g}$ ) with a diameter of $13 \mathrm{~mm}$ and a thickness of $0.8 \mathrm{~mm}$ while it became $0.6 \mathrm{~mm}$ after pre-firing. The pellets were then sintered in a muffle furnace, with a heating rate of $1{ }^{\circ} \mathrm{C} / \mathrm{min}$ and dwelling at $800{ }^{\circ} \mathrm{C}$, $1000{ }^{\circ} \mathrm{C}, 1200{ }^{\circ} \mathrm{C}$, and $1400{ }^{\circ} \mathrm{C}$ for $1 \mathrm{~h}, 1 \mathrm{~h}, 1 \mathrm{~h}$, and $4 \mathrm{~h}$, respectively, followed by cooling down to $400{ }^{\circ} \mathrm{C}$ at $2{ }^{\circ} \mathrm{C} / \mathrm{min}$. Finally, the furnace power was turned off and the pellets were 
naturally cooled down to room temperature.

\subsection{Characterization}

The particle size distribution of the original powders was measured with a Mastersizer 2000 laser size analyzer (Malvern Instrument Ltd., UK) combined with a Hydro2000MU accessory. Water was used as a dispersant. The pump speed was $2000 \mathrm{rpm}$ and the ultrasonic set was $20 \mathrm{~W}$. Relative density of the sintered pellets was measured using the Archimedes method. First, the diameter and thickness of a pellet/disk sample was measured using a digital micrometer and the apparent volume $V_{1}$ was calculated. Then the sample was weighed to get a weight value of $W_{1}$. After that, the sample was immerged in water which then was boiled for $1 \mathrm{~h}$ followed by cooling down to room temperature. At last, the sample was taken out of the water and was weighed to get a weight value of $W_{2}$. The volume of open pores of the sample was calculated according to $V_{2}=W_{2}-W_{1}$. Therefore, the relative density of the sample was $d=\left(V_{1}-V_{2}\right) / V_{1}$. A Hitachi S-3700 scanning electron microscope (SEM) coupled with an energy dispersive spectroscopy (EDS) system were employed to characterize the morphology and chemical composition of sintered samples on which a layer of Au was coated for electrical conduction. Average grain size was measured from the scanning electron micrograph of the surface of the as-sintered samples, and calculation of the grain size was carried out based on a method described by Fullman [16].

Silver electrodes with a thickness of $35 \mu \mathrm{m}$ were applied on the two opposite sides of each pellet for AC impedance measurement, by painting silver paste (DAD-87, Shanghai Research Institute of Synthetic Resins, Shanghai, China, containing $80 \mathrm{wt} \%$ Ag) on the polished surfaces followed by heating at $140{ }^{\circ} \mathrm{C}$ for $1 \mathrm{~h}$. The electrode area of all the samples 
was controlled to be the same, $0.16 \mathrm{~cm}^{2}$. The AC impedance measurements were performed with an IM6 electrochemical workstation (Zahner, Germany) under air atmosphere at $400{ }^{\circ} \mathrm{C}$ and $800{ }^{\circ} \mathrm{C}$, respectively. The amplitude voltage was $0.01 \mathrm{~V}$, and frequency range was from 8 $\mathrm{MHz}$ to $0.01 \mathrm{~Hz}$. Impedance spectra plotted in Nyquist representation was fitted to the equivalent circuit model by using the software package ZView (Scribner Associates, Southern Pines, NC, USA).

\subsection{Cell assembling and testing}

SOFCs, with pure YSZ and $\mathrm{Al}_{2} \mathrm{O}_{3}$-doped-YSZ of selected doping amount as electrolytes, were fabricated. A composite cathode paste, composed of $1.2 \mathrm{~g} \mathrm{LSM}\left(\mathrm{La}_{0.7} \mathrm{Sr}_{0.3} \mathrm{MnO}_{3}, \mathrm{Ningbo}\right.$ Institute of Material Technology and Engineering, Chinese Academy of Sciences) and $0.8 \mathrm{~g}$ YSZ, was prepared by mixing the LSM and YSZ powders in an agate motar and grinding the mixture for $3 \mathrm{~h}$ with $3 \mathrm{~g}$ PVB (polyviyl butyral) terpineol solution of $10 \mathrm{wt} . \%$ concentration, as binder. The same process was used for preparing a pure LSM paste. A composite LSM-YSZ functional layer and a pure LSM current collecting layer were sequentially applied on one side of a YSZ electrolyte substrate by brush painting, and then dried at $120{ }^{\circ} \mathrm{C}$ and co-sintered at $1100{ }^{\circ} \mathrm{C}$ for $2 \mathrm{~h}$, with a heating rate of $2{ }^{\circ} \mathrm{C} / \mathrm{min}$ [17]. The cathode area of all the single cells was controlled to be the same, $0.25 \mathrm{~cm}^{2}$.

A cermet of $\mathrm{Ag}$ and GDC (gadolinium doped ceria, $\mathrm{Ce}_{0.8} \mathrm{Gd}_{0.2} \mathrm{O}_{1.9}$ ) was used as the anode material because $\mathrm{Ag}$ is a good electronic conductor and has high catalysis activity to promote the oxidation of fuel gas, while GDC, with high ionic conductivity, combined with Ag, can provide more three phase boundaries for the electrochemical oxidation of fuel gas

[18-20]. $1.75 \mathrm{~g}$ sliver paste, $0.6 \mathrm{~g}$ GDC powder (Ningbo Institute of Material Technology and 
Engineering, Chinese Academy of Sciences), and 3 g 10 wt.\% PVB terpineol solution were mixed by grinding the mixture with an agate mortar for $3 \mathrm{~h}$ to get a Ag-GDC paste [21]. Then the obtained homogeneous paste was painted on the whole surface of the other side of the YSZ electrolyte substrate and dried at $120^{\circ} \mathrm{C}$, followed by annealing at $880{ }^{\circ} \mathrm{C}$ for $4 \mathrm{~h}$ with a heating rate of $2^{\circ} \mathrm{C} / \mathrm{min}$.

Each single SOFC was attached to one end of an alumina tube by using silver paste as sealing and joining material [22-23]. The electrochemical performance of the cells, with humidified hydrogen ( 3 vol.\% water, $50 \mathrm{ml} / \mathrm{min}$ ) as fuel and ambient air as oxidant, was tested using an IM6 electrochemical workstation in the temperature range of $600-800{ }^{\circ} \mathrm{C}$. Silver wires were attached on the electrodes as leading wires. A four-probe setup was adopted to eliminate the ohmic loss in the silver wires. The current-voltage $(I-V)$ characteristics were tested in the range of $1.2-0.2 \mathrm{~V}$ by linear sweep voltammetry at a scanning rate of $5 \mathrm{mV} / \mathrm{s}$. For impedance measurements, an $\mathrm{AC}$ amplitude of $0.01 \mathrm{~V}$ was applied to the sample over a frequency range from $100 \mathrm{kHz}-0.1 \mathrm{~Hz}$ at various temperatures. After that, stability at $800{ }^{\circ} \mathrm{C}$ was tested under a constant current density of $0.23 \mathrm{~A} \mathrm{~cm}^{-2}$.

\section{Results and discussion}

\subsection{Powder characterization}

Fig. 1 shows the SEM images of the raw $\mathrm{Al}_{2} \mathrm{O}_{3}$ powder (a) and the $\mathrm{Al}_{2} \mathrm{O}_{3}$ powder calcined at $1400{ }^{\circ} \mathrm{C}(\mathrm{b})$. Obviously, the particle size of the raw powder is smaller than the sintered one. The fact is consistent with the measured particle size distribution of the two powders as shown in Fig. 1(c) and (d). The modal particle size of the raw powder is $0.28 \mathrm{~m}$ 
while that of the sintered powder is $0.45 \mathrm{~m}$.

In a unit weight of powder, the number of particles with a diameter of around $d_{\mathrm{i}}$ is

$$
N_{i}=\frac{6 f_{i}}{\pi \rho_{A} d_{i}^{3}}
$$

where $f_{\mathrm{i}}$ is the volume fraction of the particles with diameter of $d_{\mathrm{i}}$ and $\rho_{A}$ is the real density of the material. The number of particles with diameter range in $d_{\mathrm{i} 1}-d_{\text {in }}$ is

$$
N_{i_{1}-i_{n}}=\sum_{i_{1}}^{i_{n}} \frac{6 f_{i}}{\pi \rho d_{i}^{3}}
$$

Therefore, the space distribution distance (the nearest distance of two adjacent particles based on a cubic lattice model), presuming the particles distribute in the jointing sites of a cubic lattice, of alumina with different doping amount in the YSZ can be calculated by

$$
d_{s d}=\left(\frac{V_{Y S Z}}{N_{a}}\right)^{1 / 3}
$$

where $d_{s d}$ is the space distribution distance of alumina particles in the YSZ substrate, $N_{a}$ is the total number of alumina particles, and $V_{Y S Z}$ is the volume of YSZ, respectively. According to the data of Fig. 1(c) and (d), the space distribution distances of alumina particles in the alumina-doped YSZ are calculated and the results are shown in Fig. 2 (a). When there is no alumina doping, the calculated $d_{\text {sd }}$ goes to infinity. When there is alumina doping, $d_{\text {sd }}$ decreases with the doping amount increasing. Fig.2 (b) shows that there is a close correlation between the space distribution distance and the grain size of the alumina doped YSZ, and this will be further analyzed in the following discussion.

\subsection{Microstructure}

Previous study has shown that alumina exists in zirconia in three forms: (1) a very small 
amount of alumina dissolved in zirconia grains/crystallines (about $0.48 \mathrm{wt} . \%$ in YSZ sintered at $\left.1500{ }^{\circ} \mathrm{C}\right)$ [24], (2) alumina particles, which are extensively situated at grain boundaries, and (3) crystals and amorphous alumina-rich grain boundary phases [25]. The scanning electron micrographs of the surfaces of the as-sintered electrolytes are shown in Fig. 3. The morphology of the grains and grain boundaries of the YSZ, along with the scattered alumina particles, can be clearly seen. When a small amount $(\leq 0.7 \mathrm{wt} . \%)$ of alumina is doped into the YSZ, the grain size increases with the increasing amount of doping until 0.7 wt.\%. When the doping amount increases further, the grain size decreases. The corresponding grain sizes, obtained from these images, are summarized in Fig. 2 (a). It can be seen that when the doping amount is larger than $0.7 \mathrm{wt} . \%$, there is a close correlation between the space distribution distance of the doping alumina and the grain size of the doped YSZ, i.e., smaller space distribution distance corresponds to smaller grain size, as shown in Fig.2 (b). This indicates the importance of dopant particle distribution in determining the grain size of the doped YSZ. For example, the YSZ doped with 0.7 wt. $\% 1400{ }^{\circ} \mathrm{C}$-calcined- $\mathrm{Al}_{2} \mathrm{O}_{3}$, with larger particle size, has few pores trapped in the grains and there are rarely pores or alumina particles at the grain boundaries. Meanwhile, the sample with the same amount (by mass) of raw alumina, with a space distribution space distance twice as that of the pre-calcined alumina, has much more pores and alumina particles distributed both at the grain boundaries (as marked with a square in Fig. 3(g) and named as "g1") and within the grains (as marked with a square in Fig.3 (e) and named as "e1"). With the alumina doping amount increasing, its particles tend to mainly locate at the grain boundaries. It is reasonable to presume that, in these cases, the alumina particles distributed at the grain boundaries are functioning as pins which protect the grain 
boundaries from merging. This can well explain the facts that smaller space distribution distance, with more particles pinning the grain boundaries, reserving more grain boundaries and result in smaller grain size. Very distinct evidences can be found by comparing Fig. 3(g) with Fig. 3(h), and Fig. 3(i) with Fig. 3(j). For the same weight of $\mathrm{Al}_{2} \mathrm{O}_{3}$ doping, the raw $\mathrm{Al}_{2} \mathrm{O}_{3}$, with smaller space distribution distance, gives smaller grain size. Fig. 3(e1) shows the EDS analysis result for the small square part of Fig.3 (e) where a dispersed particle at the grain boundary is located in. Fig. 3(g1) shows the result of the square part of Fig.3 (g) where a particle in the grain is located in. The quantitative information is also shown in Fig.3 (el) and Fig. $3(\mathrm{~g} 1)$. It is obvious that $\mathrm{Al}$ is a main constituent of these particles. The $\mathrm{Y}$ and $\mathrm{Zr}$ peaks can be attributed to the surrounding of the dispersed particles.

\subsection{Sintering behavior}

The sintering behavior, characterized by relative density, of the $\mathrm{Al}_{2} \mathrm{O}_{3}$-doped-YSZ samples are shown in Fig. 4. It can be seen that there is an optimum doping amount for either raw (3 wt. $\%$ ) or $1400{ }^{\circ} \mathrm{C}$-calcined ( $4 \mathrm{wt} . \%$ ) alumina dopant to get the best sinterability. As the doping amount is less than the optimum one, the relative density decreases with decreasing dopant, while as the dopant is more than the optimum, the sintering behavior becomes worse with the increasing dopant.

It has been recognized that when a small amount of impurity is introduced into a main crystal substrate, the impurity may be dissolved into the substrate lattice, creating point defects that will promote diffusion effect to improve the sinterability of the substrate [26]. This can partly explain the densification effect of doping small amount of alumina into YSZ. Besides, in the zirconia system, the $\mathrm{Al}_{2} \mathrm{O}_{3}$ addition has a dual effect on grain growth [27]: 
First, the alumina segregated at grain boundaries can promote grain growth by improving the mobility of the boundaries. Second, the alumina particles pin grain boundaries, as mentioned above. While the first effect favors the sintering, the second one is always accompanied by pores because of the quite large differences in the elastic modulus and the thermal expansion coefficient between alumina and zirconia [12], which can be quantified from the relative density. The pores accompanied with the doping alumina particles can also be explained by minimization of free energy of interfaces that the free energy of alumina/air interface (or alumina surface) is smaller than those of YSZ/air and $\mathrm{YSZ} / \mathrm{Al}_{2} \mathrm{O}_{3}$ interfaces [14]. The overall effect of doping $\mathrm{Al}_{2} \mathrm{O}_{3}$ on the sintering behavior of $\mathrm{YSZ}$ is actually a trade-off between the above two effects. When the doping amount is small, the first effect dominates. As the dopant approaches to the optimum value, the mobility of grain boundaries reaches the maximum and then the second effect dominates. Moreover, the density of the specimen doped with raw $\mathrm{Al}_{2} \mathrm{O}_{3}$ powder is always smaller than that doped with $1400{ }^{\circ} \mathrm{C}-\mathrm{Al}_{2} \mathrm{O}_{3}$ powder because the space distribution distance of the former is smaller than the latter, and more pores are accompanied with more particles of the former specimen.

\subsection{Electrical conductivity}

Fig. 5 shows typical impedance spectra of YSZ doped with 1 wt. $\% 1400{ }^{\circ} \mathrm{C}$-calcined $\mathrm{Al}_{2} \mathrm{O}_{3}$ measured at $400{ }^{\circ} \mathrm{C}(\mathrm{a})$ and $800{ }^{\circ} \mathrm{C}(\mathrm{b})$, respectively. The measuring temperature of 800 ${ }^{\circ} \mathrm{C}$ is selected based on the concern of using the $\mathrm{Al}_{2} \mathrm{O}_{3}$-doped YSZ as the electrolyte of a SOFC with typical operating temperature of $800{ }^{\circ} \mathrm{C}$. However, at such high temperature, the conductivity contribution from the bulk (or grain) and grain boundary cannot be distinguished. Therefore, a lower measuring temperature, $400{ }^{\circ} \mathrm{C}$, is applied. The corresponding equivalent 
circuits for the impedance spectra have also been provided in the figure, where $R_{\mathrm{p}}$ is the polarization resistance and $W$ is the diffusion resistance of oxygen ion [28]. $R_{\mathrm{p}}$ and $W$ have close relation to the properties of the electrodes but not the measured sample (electrolyte). Their values have little to do with the measured electrolyte, thus are not considered in analyzing the properties of the $\mathrm{Al}_{2} \mathrm{O}_{3}$ doped YSZ. In Fig.5 (a), the semicircles at the left and in the middle, represent the resistances of bulk $\left(R_{\mathrm{b}}\right)$ and grain boundary $\left(R_{\mathrm{gb}}\right)$, respectively. $R_{\mathrm{b}}$ and $R_{\mathrm{gb}}$ constitutes the total resistance of the measured sample, i.e., $R_{\mathrm{total}}=R_{\mathrm{b}}+R_{\mathrm{gb}}$. As the total resistance of the sample $R_{\text {total }}$ follows Ohm's Law, it is generally called as ohmic resistance. Because YSZ is a pure oxygen ionic conductor, its $R_{\text {total }}$ can also been taken as the total ionic resistance.

Based on the equivalent circuit of ionic conductor proposed by Bauerle [28], the resistance of bulk and grain boundary can be calculated through fitting the experimental data. Fig.6 (a) shows the total ionic conductivity and Fig.6 (b) shows the bulk and grain boundary conductivity as a function of doping amount of $\mathrm{Al}_{2} \mathrm{O}_{3}$, measured at $400{ }^{\circ} \mathrm{C}$. As can be seen from Fig.6 (a), the total ionic conductivity of the samples, doped with either raw $\mathrm{Al}_{2} \mathrm{O}_{3}$ powder or $1400^{\circ} \mathrm{C}$-calcined $\mathrm{Al}_{2} \mathrm{O}_{3}$ powder, increases with the doping amount until a maximum value is attained when the doping amount is less than $1 \mathrm{wt} . \%$. When the doping amount is larger than 1 wt.\%, the conductivity decreases with the doping amount. Fig.6 (b) shows that the bulk conductivity does not change much with the $\mathrm{Al}_{2} \mathrm{O}_{3}$ doping while the grain boundary conductivity is very sensitive to it. When the doping amount is $1 \mathrm{wt} . \%$, the grain boundary conductivity of the sample doped with raw $\mathrm{Al}_{2} \mathrm{O}_{3}$ doping is more than twice of its bulk conductivity and that doped with $1400{ }^{\circ} \mathrm{C}$-calcined $\mathrm{Al}_{2} \mathrm{O}_{3}$ is more than four times larger 
than the bulk conductivity. For the samples with $\mathrm{Al}_{2} \mathrm{O}_{3}$ doping amount in the range of 0.7-9 wt. $\%$, the grain boundary conductivity dominates the total ionic conductivity of the sample. This evidence shows the significant impact of doping $\mathrm{Al}_{2} \mathrm{O}_{3}$ on the grain boundaries. This increase in grain boundary conductivity has been reported previously $[7,12,24]$ and the results obtained here is consistent with those reported by Feighery et al. [29].

However, the contribution of the bulk and grain boundary to the total conductivity of the electrolyte cannot be distinguished by the impedance measured at $800{ }^{\circ} \mathrm{C}$ because the semi-circle attributed to grain boundary resistance does not appear (Fig. 5b). The only semi-circle represents the polarization resistance $R_{\mathrm{p}}$. As the $x$ axis intercept at low frequency corresponds the total resistance of the testing system, the intercept at high frequency should be the total ionic resistance (or ohmic resistance $R_{\mathrm{o}}$ ), which is the sum of the bulk and grain boundary resistances. Based on this, the ohmic resistance, also represents the ionic resistance, of the $\mathrm{Al}_{2} \mathrm{O}_{3}$-doped-YSZ is obtained, from which the area specific conductivity can be calculated. The area specific resistance of the $\mathrm{Al}_{2} \mathrm{O}_{3}$-doped YSZ is plotted as a function of doping amount, as shown in Fig. 6(c). As can be seen, the conductivity of the YSZ without doping is $0.045 \mathrm{~S} / \mathrm{cm}$, which is higher than the reported value, $0.025 \mathrm{~S} / \mathrm{cm}$ [30], but lower than those obtained from the specimens with alumina doping in the range of $0.4-5 \mathrm{wt} . \%$, as presented in this study. For the specimen doped with 0.7 wt.\% raw $\mathrm{Al}_{2} \mathrm{O}_{3}$, the conductivity increases to $0.067 \mathrm{~S} / \mathrm{cm}$, an increase of almost $49 \%$, compared to that of the pure YSZ. However, when the doping is above $0.7 \mathrm{wt} . \%$, the conductivity then rapidly decreases with the increasing doping. The ionic conductivity of the specimens doped with 1400 ${ }^{\circ} \mathrm{C}$-calcined- $\mathrm{Al}_{2} \mathrm{O}_{3}$ powder shows the same trend, only the conductivity reaches its highest 
value, $0.071 \mathrm{~S} / \mathrm{cm}$, when the alumina mass fraction is $1 \mathrm{wt} . \%$. Here, the trend of conductivity change with doping amount is quite similar to that of the grain size shown in Fig. 2, which is reasonable because grain conductivity dominates the conductivity at high temperatures, and larger grain size leading to less grain boundaries, gives higher conductivity. This can be clearly seen from Fig. 6(d). Therefore, the conductivity of the $\mathrm{Al}_{2} \mathrm{O}_{3}$-doped-YSZ is also closely correlated to the distribution of the dopant particles.

Note that the density also affects the electrical conductivity. Nomura et al. suggested a correction method of electrical conductivity with relative density [31]. Using this method, we made corrections considering both the effects of pore and $\mathrm{Al}_{2} \mathrm{O}_{3}$ addition. The curves of conductivity, including the measured conductivity and the corrected ones, obtained considering the effects of pore (relative density) and $\mathrm{Al}_{2} \mathrm{O}_{3}$ addition, vs. $\mathrm{Al}_{2} \mathrm{O}_{3}$ doping amount are also shown in Fig.6 (c). It can be seen that even corrected by the relative density, the conductivities of the $\mathrm{YSZ}$ with $\mathrm{Al}_{2} \mathrm{O}_{3}$ doping amount in the range of $0.4-4$ wt.\% are obviously higher than that of the pure YSZ. Therefore, the enhancement of conductivity by adding $\mathrm{Al}_{2} \mathrm{O}_{3}$ into $\mathrm{YSZ}$ is not only because of the improvement of sintering behavior.

\subsection{SOFC performances}

Fig. 7 shows a typical current-voltage $(I-V)$ and current-power $(I-P)$ characteristics of the electrolyte-supported SOFCs at $800{ }^{\circ} \mathrm{C}$ (a) along with the corresponding impedance spectra measured under open circuit voltage (b). As can be seen from Fig.7 (a), the open circuit voltages $(\mathrm{OCVs})$ are around $1.05 \mathrm{~V}$, slightly lower than the theoretical values calculated from the Nernst equation $(1.1 \mathrm{~V})$, implying that a small gas leakage exists in the system. The cell with 1 wt. $\% 1400{ }^{\circ} \mathrm{C}$-calcined- $\mathrm{Al}_{2} \mathrm{O}_{3}$-doped $\mathrm{YSZ}$ electrolyte reveals the highest maximum 
power densities of $218.9 \mathrm{~mW} \mathrm{~cm}{ }^{-2}$, while the one doped with $0.7 \mathrm{wt} . \%$ raw alumina powder gives the second highest output of $206.7 \mathrm{~mW} \mathrm{~cm}^{-2}$. Both are larger than that with pure YSZ electrolyte $\left(174.5 \mathrm{~mW} \mathrm{~cm}^{-2}\right)$. Fig.7 (b) shows that the polarization resistances of all the three SOFCs are almost the same, $\sim 0.65 \mathrm{~cm}^{2}$, while the ohmic resistance of the SOFC with $\mathrm{Al}_{2} \mathrm{O}_{3}$ doped YSZ electrolyte, $0.9 \mathrm{~cm}^{2}$, is smaller than that without doping, $1.4 \mathrm{~cm}^{2}$. These evidences confirm that alumina addition can improve the electrical performance of YSZ electrolyte, thus the corresponding SOFC performance can be improved.

To inspect the electrochemical stability of $1 \mathrm{wt} . \% 1400{ }^{\circ} \mathrm{C}-\mathrm{Al}_{2} \mathrm{O}_{3}$-doped $\mathrm{YSZ}$ electrolyte, the durability of the cell was examined at $800{ }^{\circ} \mathrm{C}$ under constant current density of $0.23 \mathrm{~A}$ $\mathrm{cm}^{-2}$ using humidified $\mathrm{H}_{2}$ as fuel. As shown in Fig. 8, the cell displays a relatively stable performance up to $16 \mathrm{~h}$ after an initial equilibration time under the testing conditions, which suggests that the $1 \mathrm{wt} . \% 1400{ }^{\circ} \mathrm{C}-\mathrm{Al}_{2} \mathrm{O}_{3}$-doped $\mathrm{YSZ}$ electrolyte sintered at $1400{ }^{\circ} \mathrm{C}$ is dense and has potential to be developed for practical use.

\section{Conclusion}

In summary, a proper amount of $\mathrm{Al}_{2} \mathrm{O}_{3}$ doping can effectively improve the sintering and electrical performances of YSZ electrolyte, and the optimal doping amount varies with the particle size of the doping $\mathrm{Al}_{2} \mathrm{O}_{3}$. There is a close correlation between the space distribution distance of the alumina particles and the grain size of the doped YSZ. With the same weight of doping $\mathrm{Al}_{2} \mathrm{O}_{3}$, larger particle size gives larger space distribution distance, thus corresponds to higher doping amount to get the optimum sinterability and ionic conductivity of YSZ. The enhancement of electrical conductivity of YSZ by adding $\mathrm{Al}_{2} \mathrm{O}_{3}$ is not only because of the 
improvement of sintering behavior but also the change of grain size. A single cell with $1 \mathrm{wt} . \%$ $1400{ }^{\circ} \mathrm{C}$-calcined- $\mathrm{Al}_{2} \mathrm{O}_{3}$ doped $\mathrm{YSZ}$ electrolyte reveals an output of $218.9 \mathrm{~mW} \mathrm{~cm}{ }^{-2}$ at $800{ }^{\circ} \mathrm{C}$, higher than the conventional cell with pure YSZ electrolyte $\left(174.5 \mathrm{~mW} \mathrm{~cm}^{-2}\right)$.

\section{Acknowledgement}

This work was supported by the National Science Foundation of China (NSFC, No. 21276097), the Special Funds of Guangdong Province Public Research and Ability Construction (No. 2014A010106008), Guangdong Innovative and Entrepreneurial Research Team Program, and Program of Excellent Ph.D Thesis Authors of Guangdong Province.

\section{References}

[1] S.C. Singhal, Solid State Ionics 135 (2000) 305-313.

[2] R.M. Ormerod, Chem. Soc. Rev. 32 (2003) 17-28.

[3] H.Y. Tu, J. Power Sources 127 (2004) 284-293.

[4] N.Q. Minh, Solid State Ionics 174 (2004) 271-277.

[5] R.N. Basu, A.D. Sharma, A. Dutta, J. Mukhopadhyay, Int. J. Hydrogen Energy 33 (2008) $5748-5754$

[6] K.C. Radford, R.J. Bratton, J. Mater. Sci. 14 (1979) 66-69.

[7] M.J. Verkerk, A.J.A. Winnubst, A.J. Burggraaf, J. Mater. Sci. 17 (11) (1982) 3113-3122.

[8] E.P. Butler, J. Drennan, J. Am. Ceram. Soc. 65 (10) (1982) 474-478.

[9] X. Guo, R.Z. Yuan, Solid State Ionics 80 (1995) 159-166.

[10] S.P.S. Badwal, J. Mater. Sci. 18 (1983) 3230-3242. 
[11] K. Tsukuma, E. Ueda, M. Shimada, J. Am. Ceram. Soc. 68 (1) (1985) C4.

[12] M. Miyayama, H. Yanagida, A. Asada, Am. Ceram. Soc. Bull. 64 (1985) 660-664.

[13] Y. Ji, J. Liu, Z. Lu, X. Zhao, T. He, W. Su, Solid State Ionics 126 (1999) 277-283.

[14] L.B. Lei, Y.H. Bai, J. Liu, J. Power Sources 248 (2014) 1312-1319.

[15] M. Mori, T. Abe, H. Itoh, O. Yamamoto, Y. Takeda, T. Kawahara, Solid State Ionics 74 (1994) 157-164.

[16] R.L. Fullman, J. Metals AIME Trans. 5 (1953) 447-452.

[17] Y.M. Xie, W.Z. Cai, J. Xiao, Y.B. Tang, J. Liu, M.L. Liu, J. Power Sources 277 (2015) $1-8$.

[18] Y.B. Tang, J. Liu, Acta Phys. Chim. Sin. 26 (2010) 1191-1194.

[19] Y.M. Xie, Y.B. Tang, J. Liu, J. Solid State Electr. 17 (2013) 121-127.

[20] L. Zhang, J. Xiao, Y.M. Xie, Y.B. Tang, J. Liu, M.L. Liu, J. Alloys Compd. 608 (2014) $272-277$

[21] Y.B. Tang, J. Liu, Int. J. Hydrog. Energ. 35 (2010) 11188-11193.

[22] J. Liu, W.H. Su, Z. Lv, Y. Ji, L. Pei, W. Liu, et al., Chinese Patent (2004) No. ZL 02133049.2 .

[23] J. Liu, Z. Lv, S.A. Barnett, Y. Ji, W.H. Su, in: Proceeding of the 207th Electrochemical Society Conference, Quebec PQ, Canada, vol. 7(2), 2005, p. 1992.

[24] H. Bernard, Rep. CEA-R-5090, Commissariat Al'Energie Atomique, CEN-Saclay, France, (1981) 117.

[25] X. Guo, R. Z. Yuan, J. Mater. Sci. 30 (1995) 923-931.

[26] S.P. Li, Special Ceramics Technology, Wuhan University of Technology Press, Wuhan, 
2007.

[27] S.X. Wu, R.J. Brook, Solid State Ionics 14 (1984) 123-130.

[28] J.B. Bauerle, J. Phys. Chem. Solids 30 (1969) 2657-2670.

[29] A.J. Feighery, J.T.S. Irvine, Solid State Ionics 121 (1999) 209-216.

[30] P.G. Shewmon, Trans. AIME 230 (1964) 1134-1137.

[31] K. Nomura, T. Takeuchi, S. Kamo, H. Kageyama, Y. Miyazaki, Solid State Ionics 175 (2004) 553-555. 


\section{Figures Captions}

Fig. $1 \mathrm{SEM}$ images of raw $\mathrm{Al}_{2} \mathrm{O}_{3}$ powder (a) and $1400{ }^{\circ} \mathrm{C}-\mathrm{Al}_{2} \mathrm{O}_{3}$ powder (b), along with the corresponding particle size distribution of the two powders: (c) and (d).

Fig. 2 (a) The average grain size of the $\mathrm{Al}_{2} \mathrm{O}_{3}$-doped-YSZ samples and space distribution distance of $\mathrm{Al}_{2} \mathrm{O}_{3}$ as a function of the $\mathrm{Al}_{2} \mathrm{O}_{3}$ doping amount; (b) The grain size as a function of space distribution distance of alumina particles in the $\mathrm{Al}_{2} \mathrm{O}_{3}$-doped-YSZ samples.

Fig. 3 SEM images of the surfaces of the as-sintered electrolytes. Pores and alumina particles distributed both within the grains as circled in (c) and at the grain boundaries, as squared in (c). Figure (e1) and figure (g1) are the EDS results taking from the small square part marked in (e) and (g), representing an alumina particle at a grain boundary (e1) and in a grain(g1), respectively.

Fig. 4 The relative density of the $\mathrm{Al}_{2} \mathrm{O}_{3}$-doped-YSZ samples as a function of the $\mathrm{Al}_{2} \mathrm{O}_{3}$ doping amount.

Fig. 5 A typical impedance spectra of $\mathrm{YSZ}$ doped with $1 \mathrm{wt} . \% 1400{ }^{\circ} \mathrm{C}-\mathrm{Al}_{2} \mathrm{O}_{3}$ measured at (a) $400{ }^{\circ} \mathrm{C}$ and (b) $800{ }^{\circ} \mathrm{C}$, respectively.

Fig.6 (a) Total ionic conductivity versus $\mathrm{Al}_{2} \mathrm{O}_{3}$ doping amount, measured at $400{ }^{\circ} \mathrm{C}$. (b) Bulk and grain boundary conductivity versus $\mathrm{Al}_{2} \mathrm{O}_{3}$ doping amount, measured at $400{ }^{\circ} \mathrm{C}$. (c) Conductivity, including the measured conductivity and the corrected ones considering the effects of pore (relative density) and $\mathrm{Al}_{2} \mathrm{O}_{3}$ addition, versus $\mathrm{Al}_{2} \mathrm{O}_{3}$ doping amount, measured at $800{ }^{\circ} \mathrm{C}$. (d) Total ionic conductivity measured at $800{ }^{\circ} \mathrm{C}$ as a function of grain size.

Fig. 7 (a) Voltage and power density versus current density for typical cells using humidified hydrogen as fuel and ambient air as oxidant at $800{ }^{\circ} \mathrm{C}$; (b) The impedance spectra of the 
hydrogen SOFCs measured under open circuit at $800{ }^{\circ} \mathrm{C}$.

Fig. 8 Stability test of the cell with 1 wt. $\% 1400{ }^{\circ} \mathrm{C}-\mathrm{Al}_{2} \mathrm{O}_{3}$-doped YSZ electrolyte using humidified hydrogen as fuel at $800{ }^{\circ} \mathrm{C}$. 

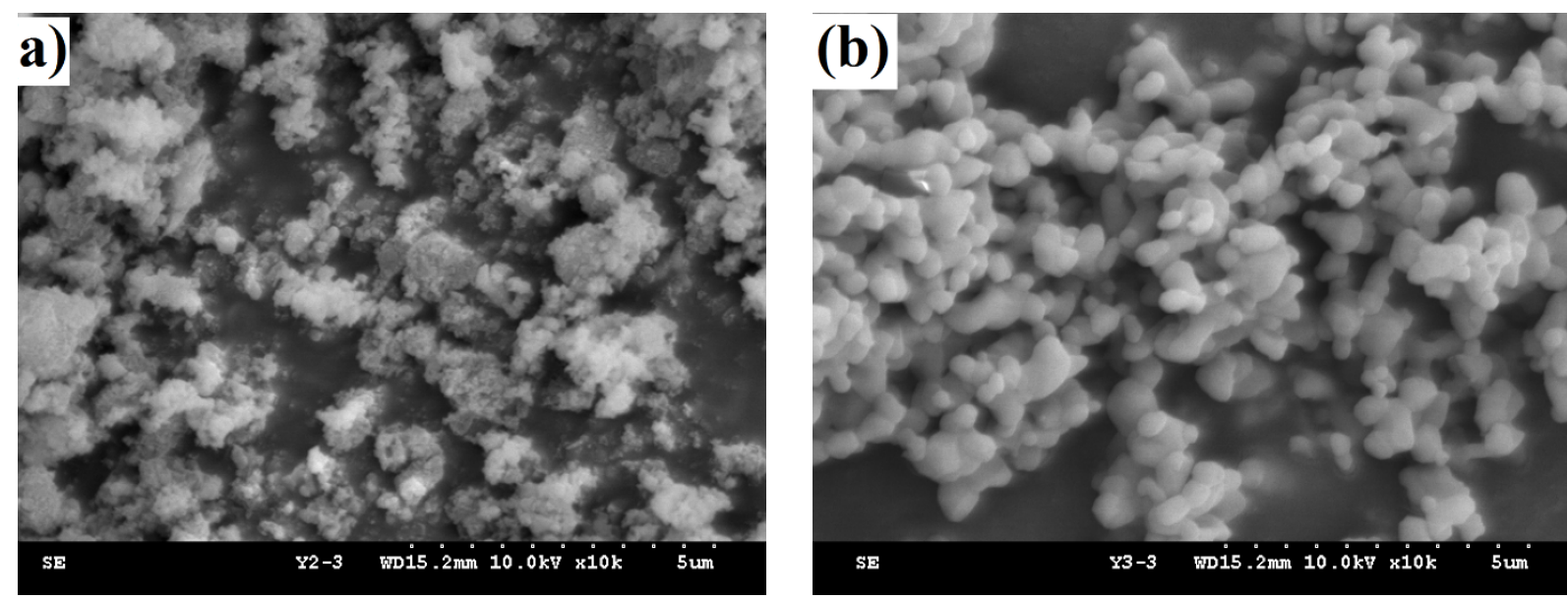

c)

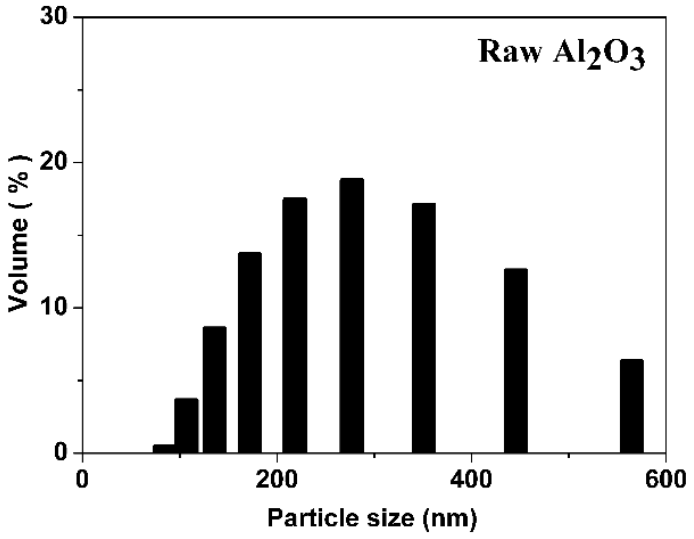

(d)

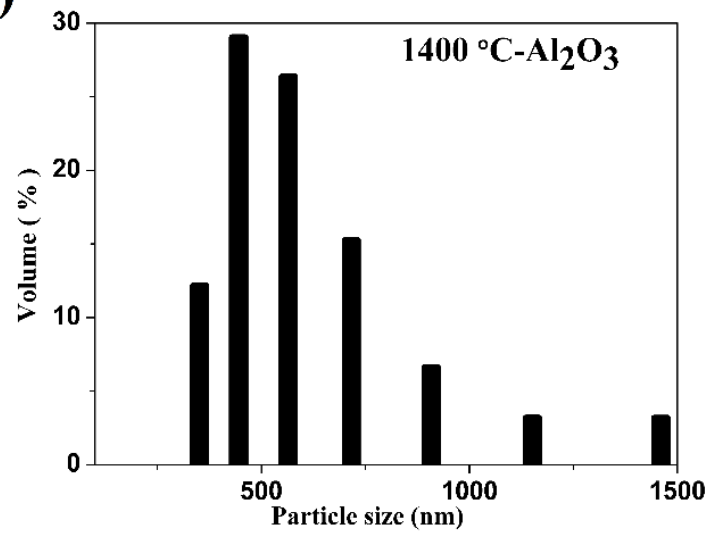

Fig.1 
(a)

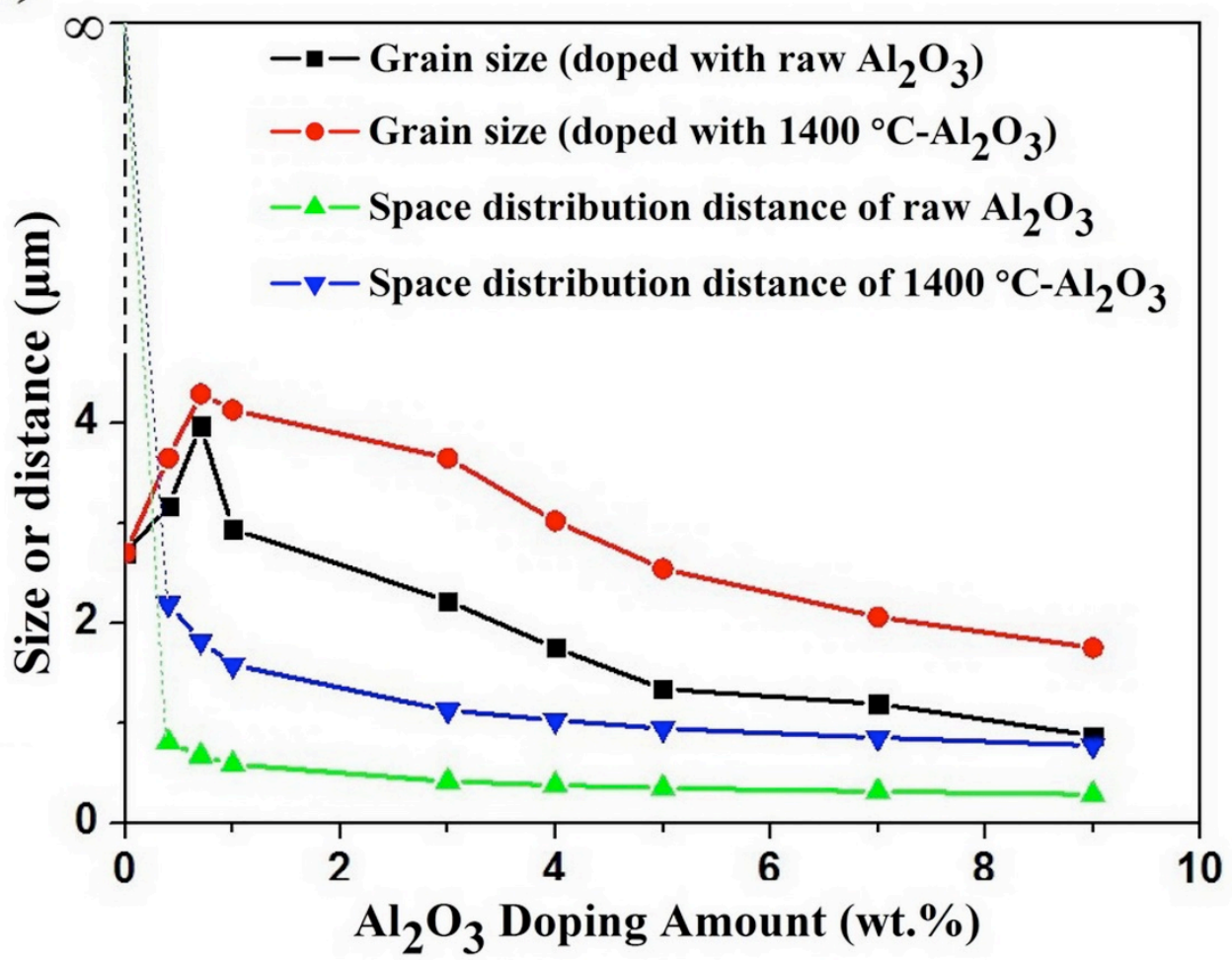

(b)

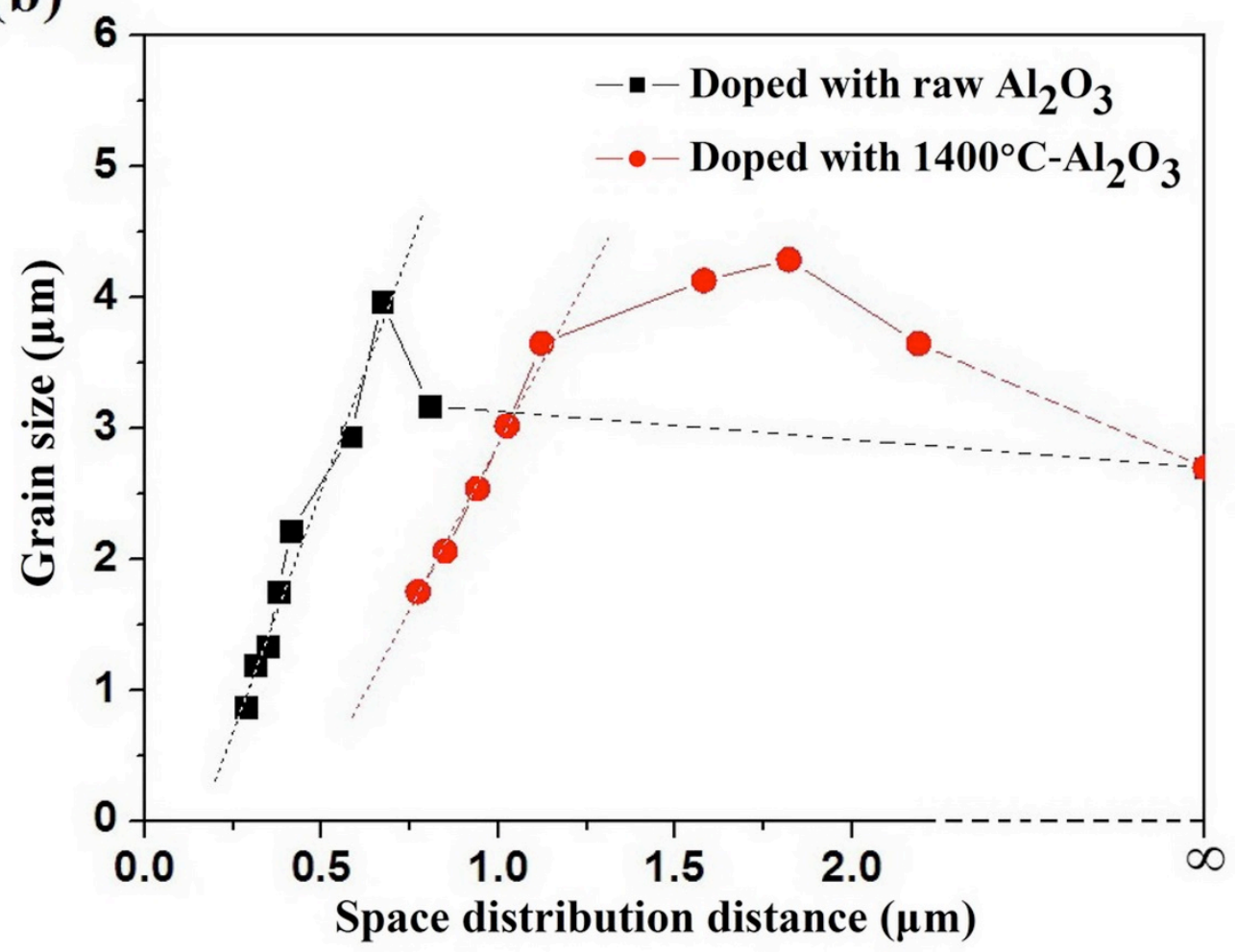

Fig.2 


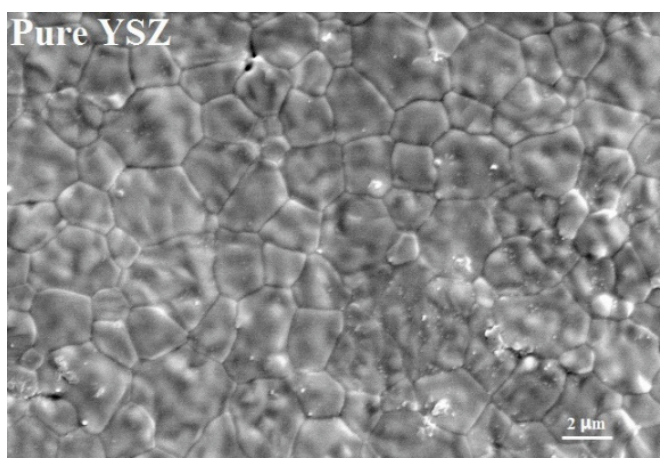

\section{Pure YSZ}

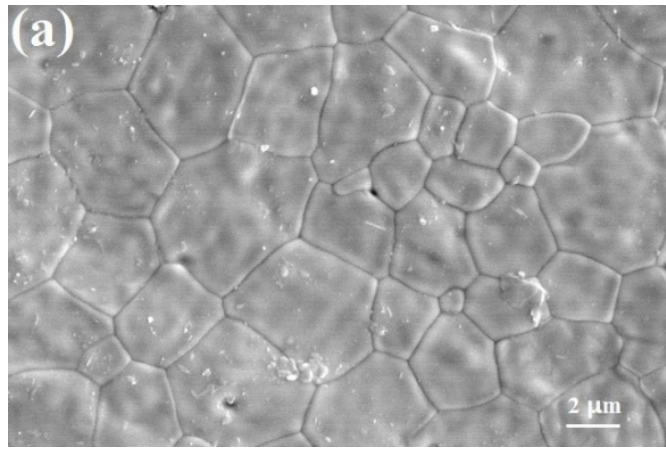

$\mathrm{YSZ}+0.4$ wt. $\%$ raw $\mathrm{Al}_{2} \mathrm{O}_{3}$

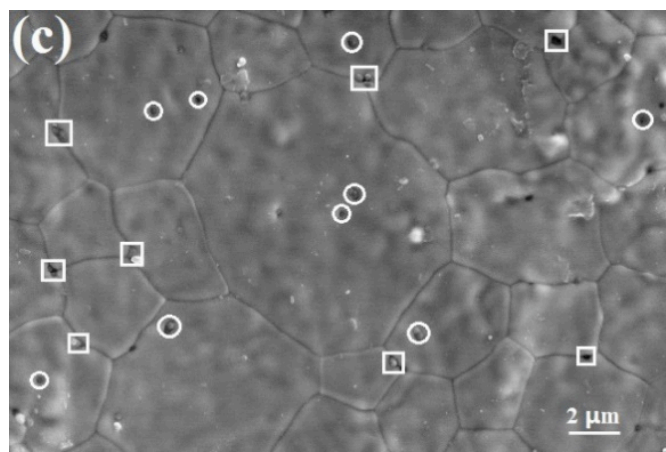

$\mathrm{YSZ}+0.7$ wt. $\%$ raw $\mathrm{Al}_{2} \mathrm{O}_{3}$

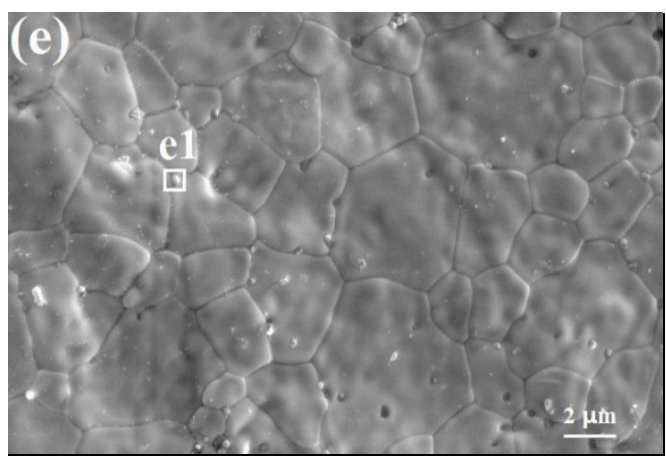

$\mathrm{YSZ}+1$ wt. $\%$ raw $\mathrm{Al}_{2} \mathrm{O}_{3}$

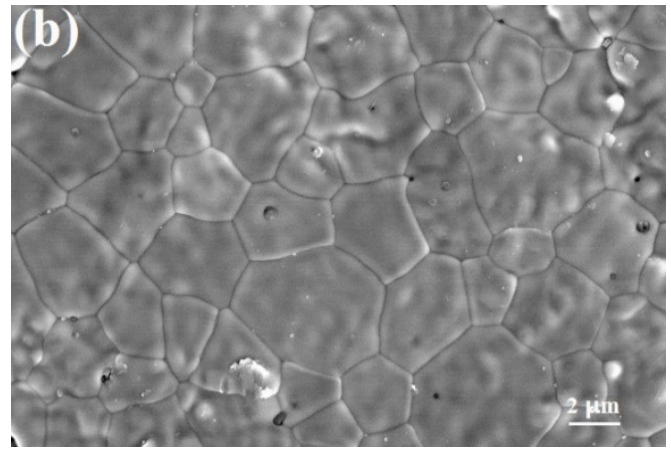

$\mathrm{YSZ}+0.4$ wt. $\% 1400{ }^{\circ} \mathrm{C}$-calcined- $\mathrm{Al}_{2} \mathrm{O}_{3}$

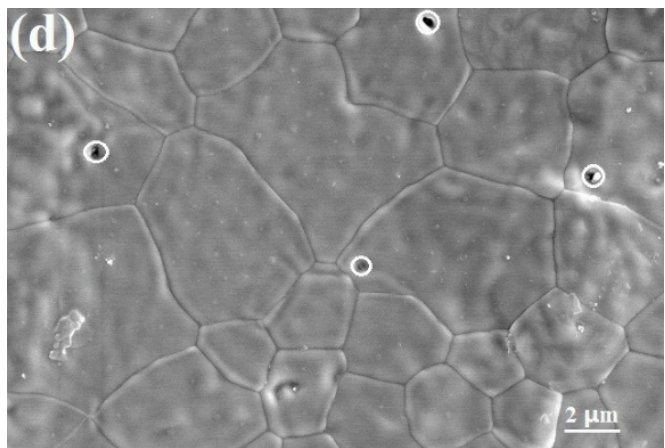

$\mathrm{YSZ}+0.7$ wt. $\% 1400{ }^{\circ} \mathrm{C}$-calcined- $\mathrm{Al}_{2} \mathrm{O}_{3}$

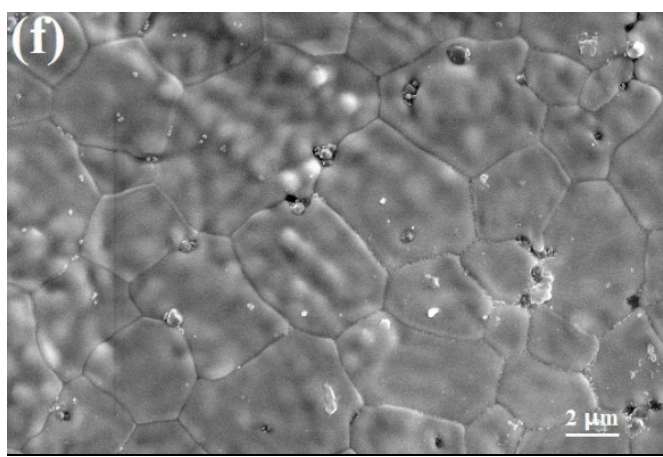

$\mathrm{YSZ}+1$ wt. $\% 1400{ }^{\circ} \mathrm{C}$-calcined- $\mathrm{Al}_{2} \mathrm{O}_{3}$ 


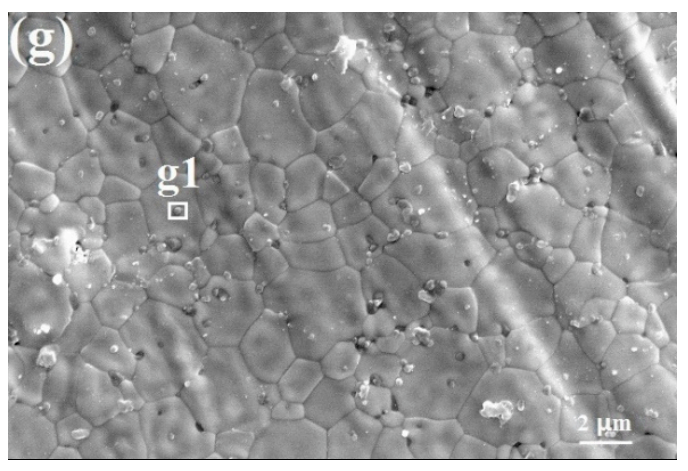

$\mathrm{YSZ}+3$ wt. $\%$ raw $\mathrm{Al}_{2} \mathrm{O}_{3}$

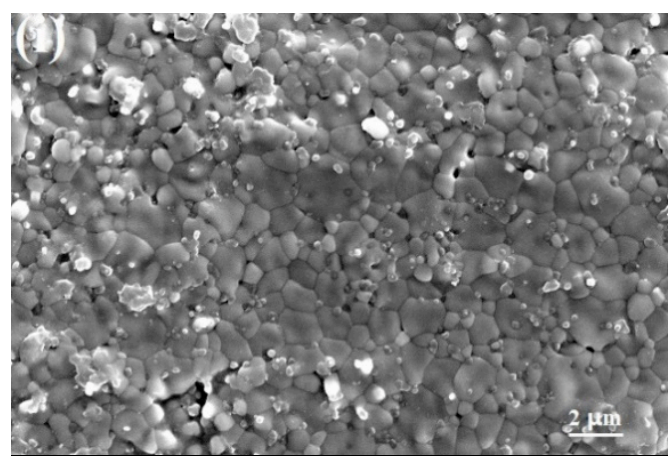

$\mathrm{YSZ}+9$ wt. $\%$ raw $\mathrm{Al}_{2} \mathrm{O}_{3}$

(e1)

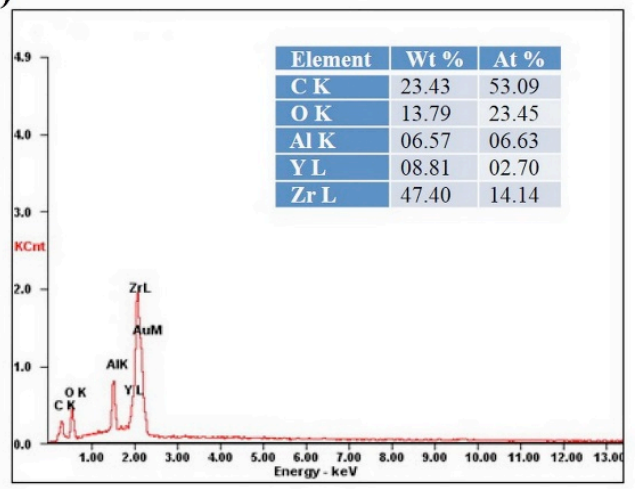

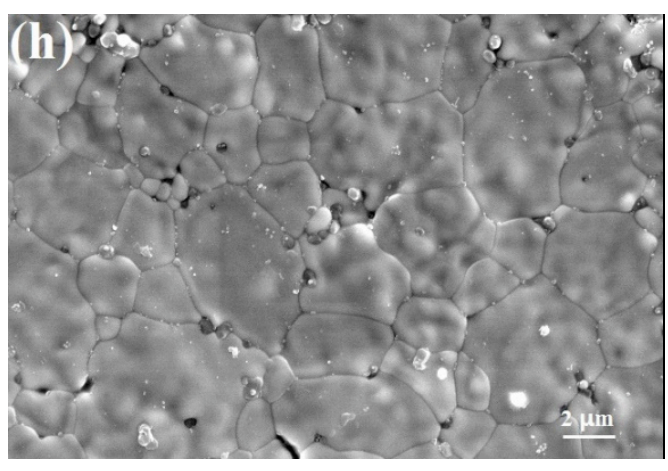

$\mathrm{YSZ}+3$ wt. $\% 1400{ }^{\circ} \mathrm{C}$-calcined- $\mathrm{Al}_{2} \mathrm{O}_{3}$

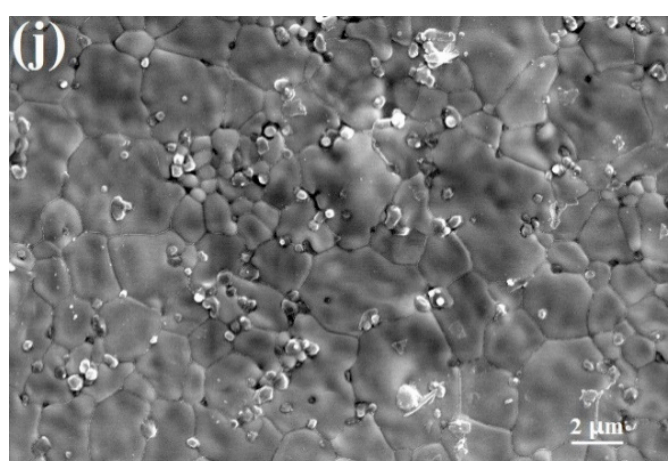

$\mathrm{YSZ}+9$ wt. $\% 1400{ }^{\circ} \mathrm{C}$-calcined- $\mathrm{Al}_{2} \mathrm{O}_{3}$

(g1)

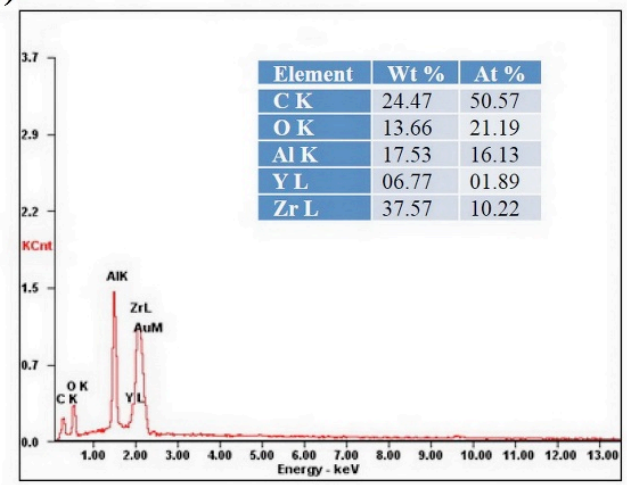

Fig. 3 


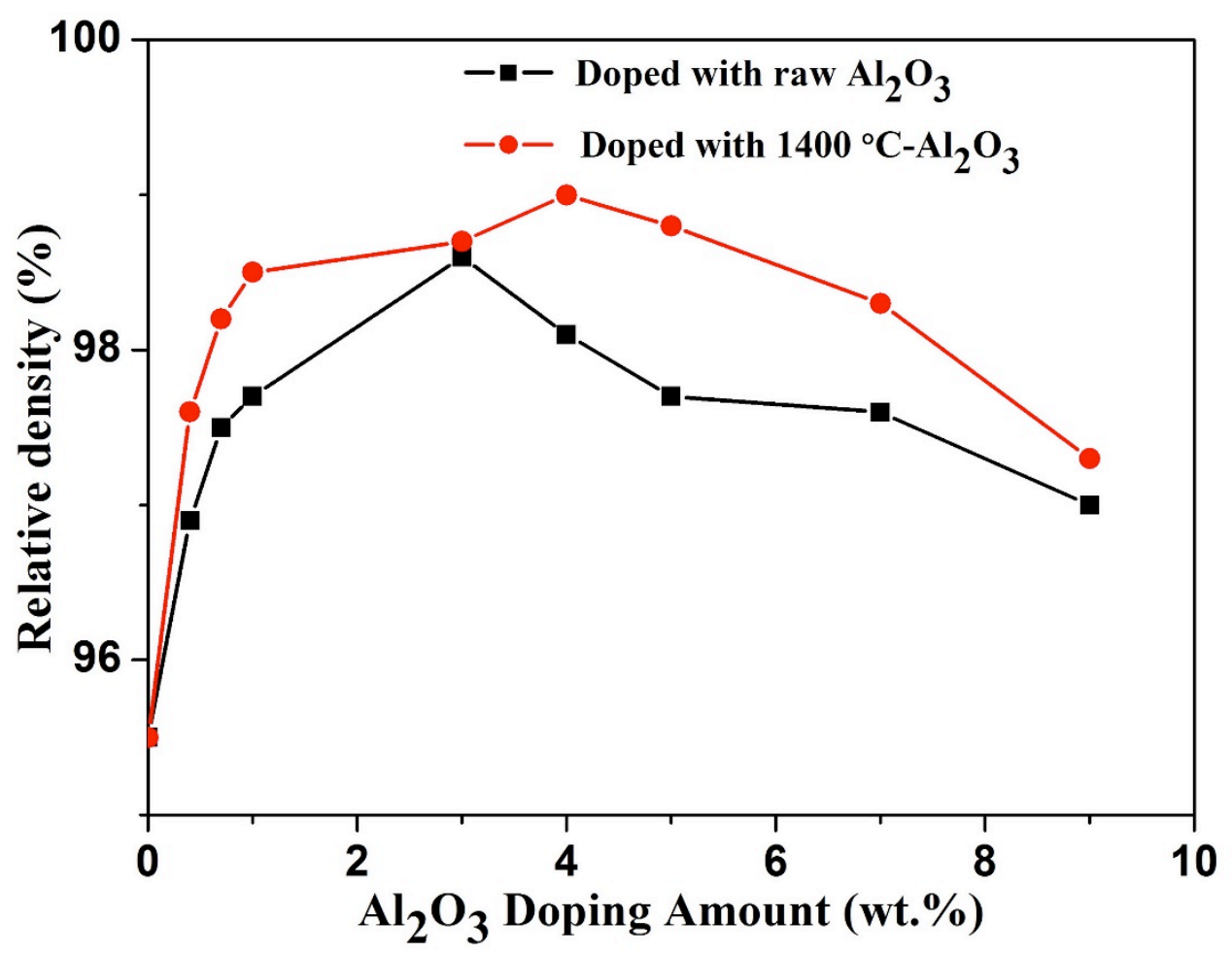

Fig. 4 
(a)

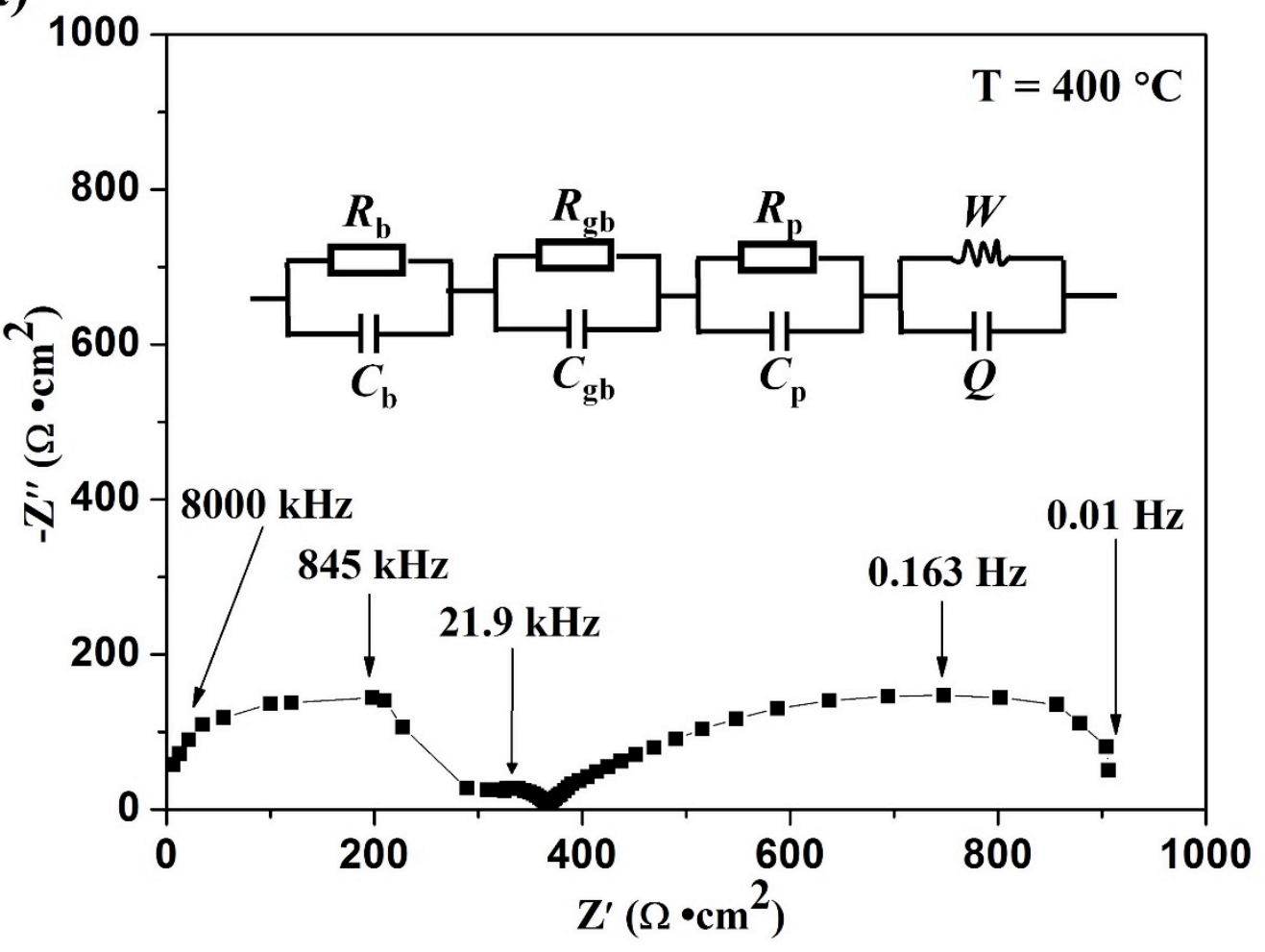

(b)

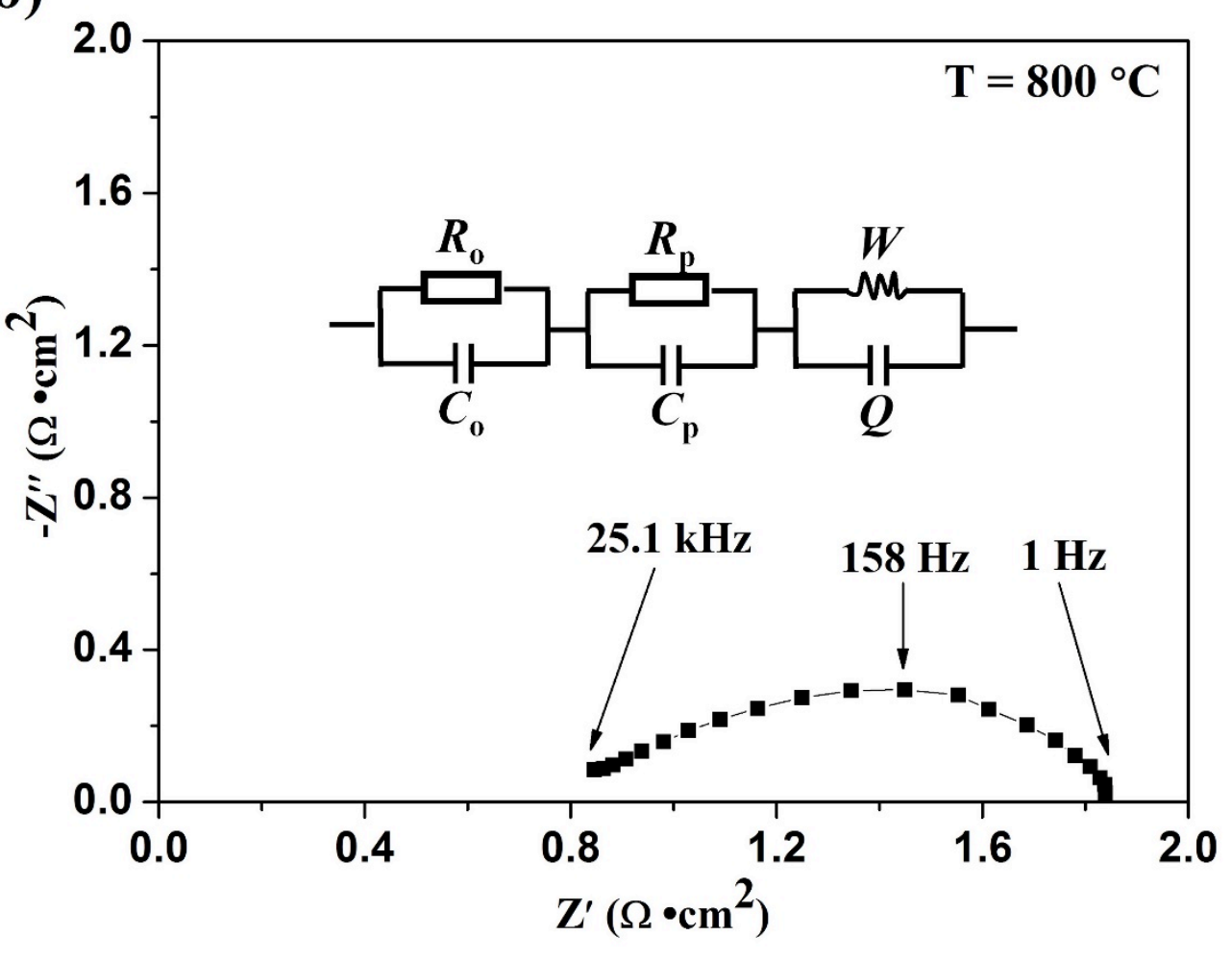

Fig. 5 

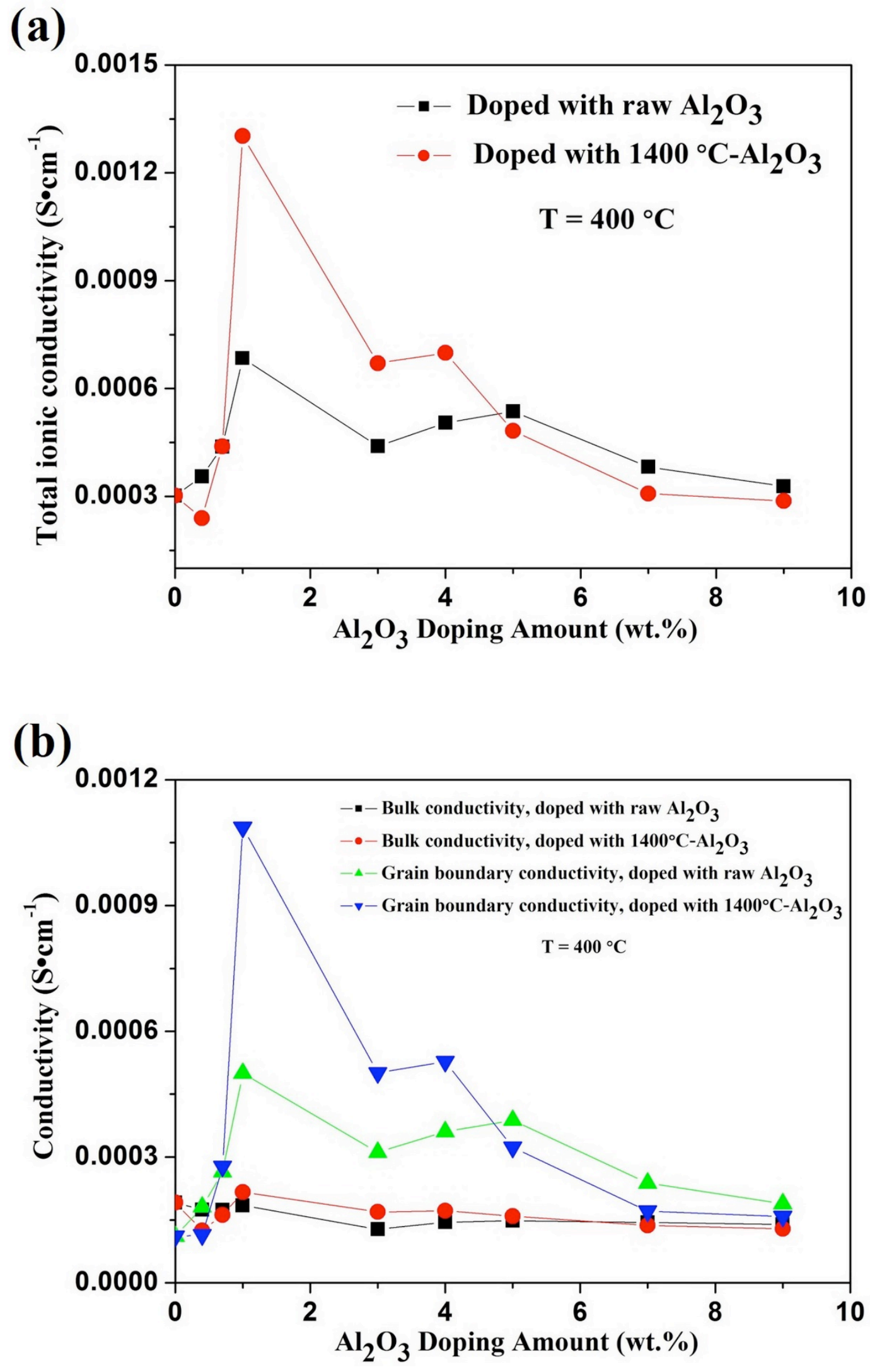

Fig.6 (to be continued) 


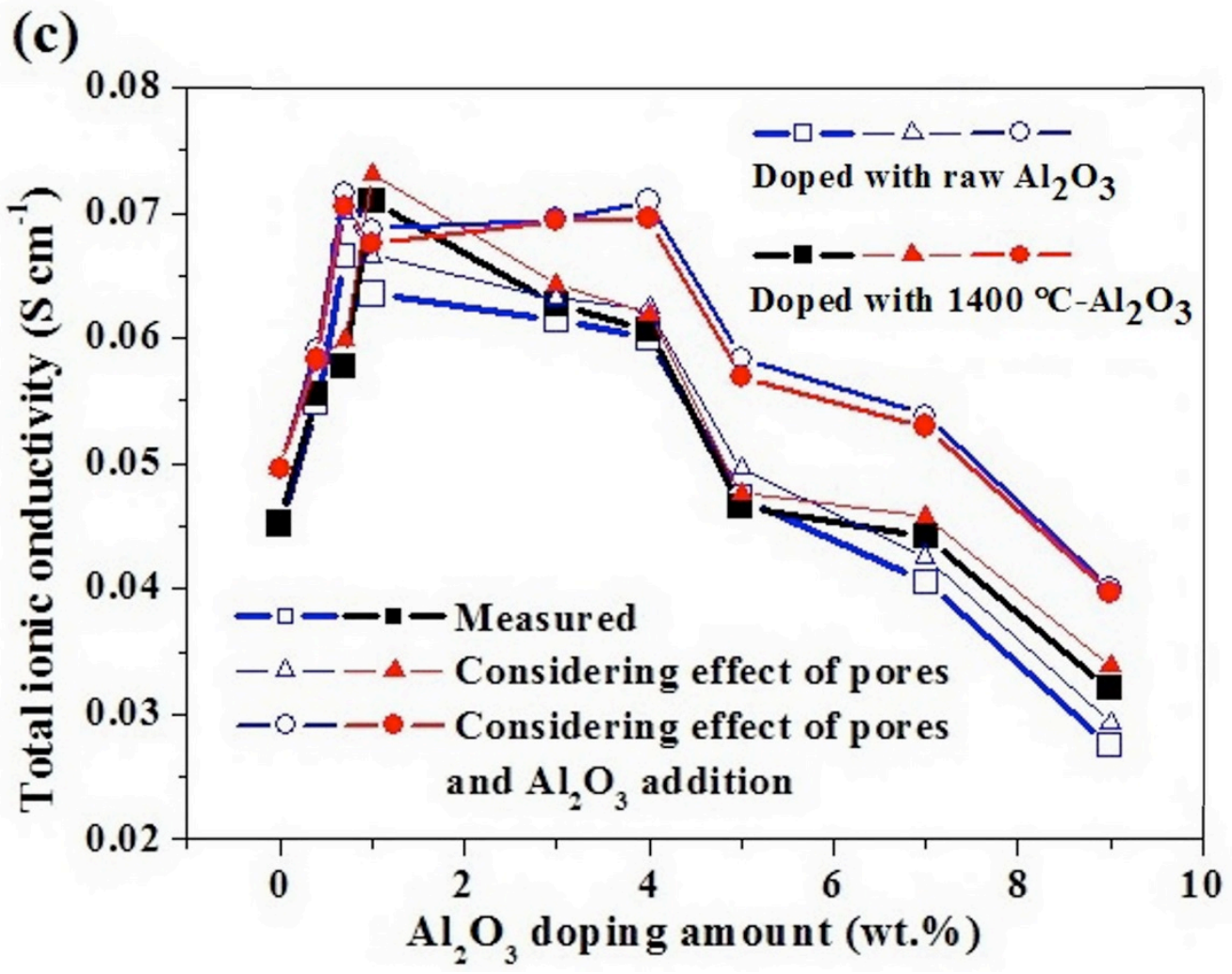

(d)

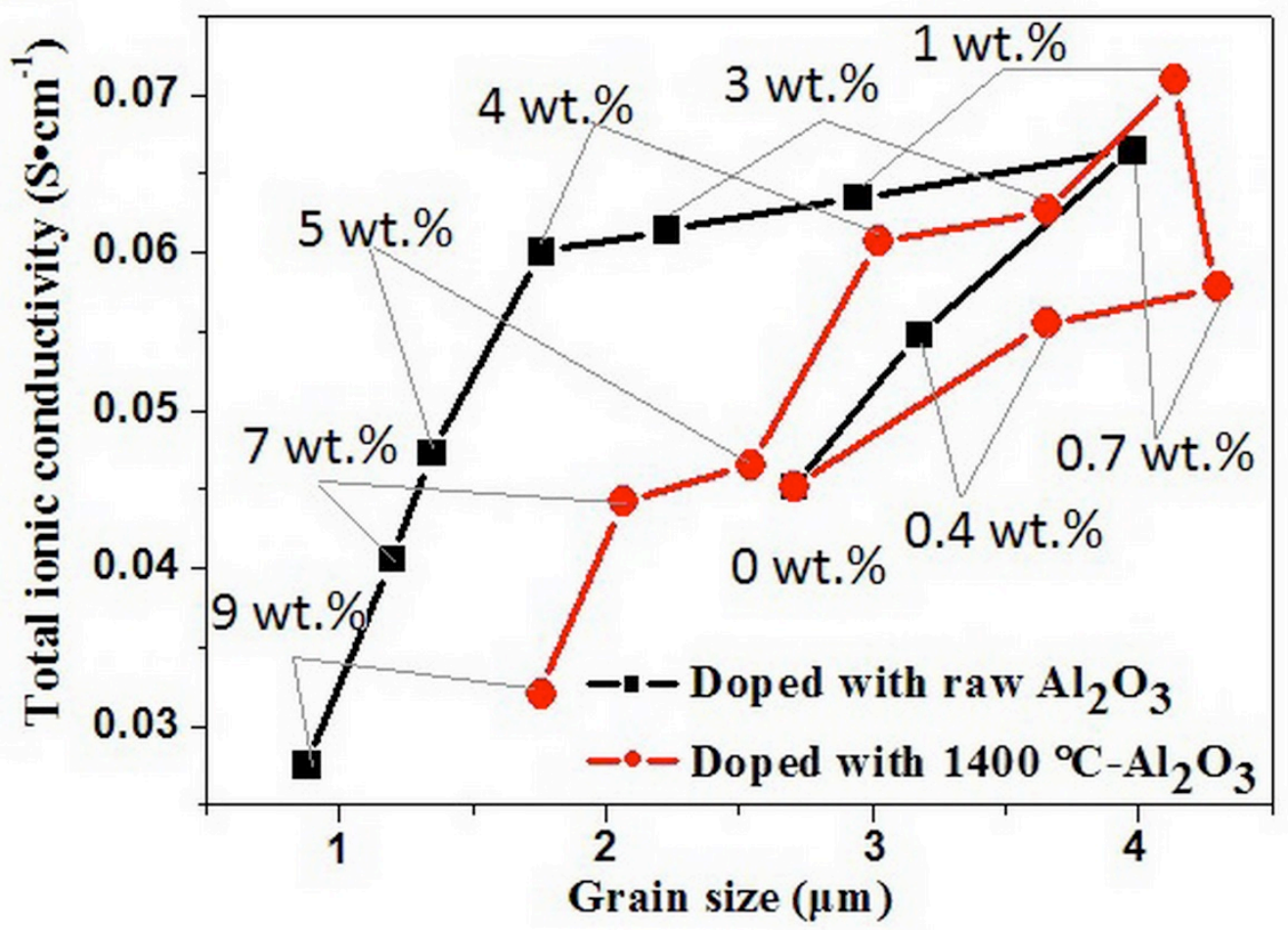

Fig. 6 
(a)

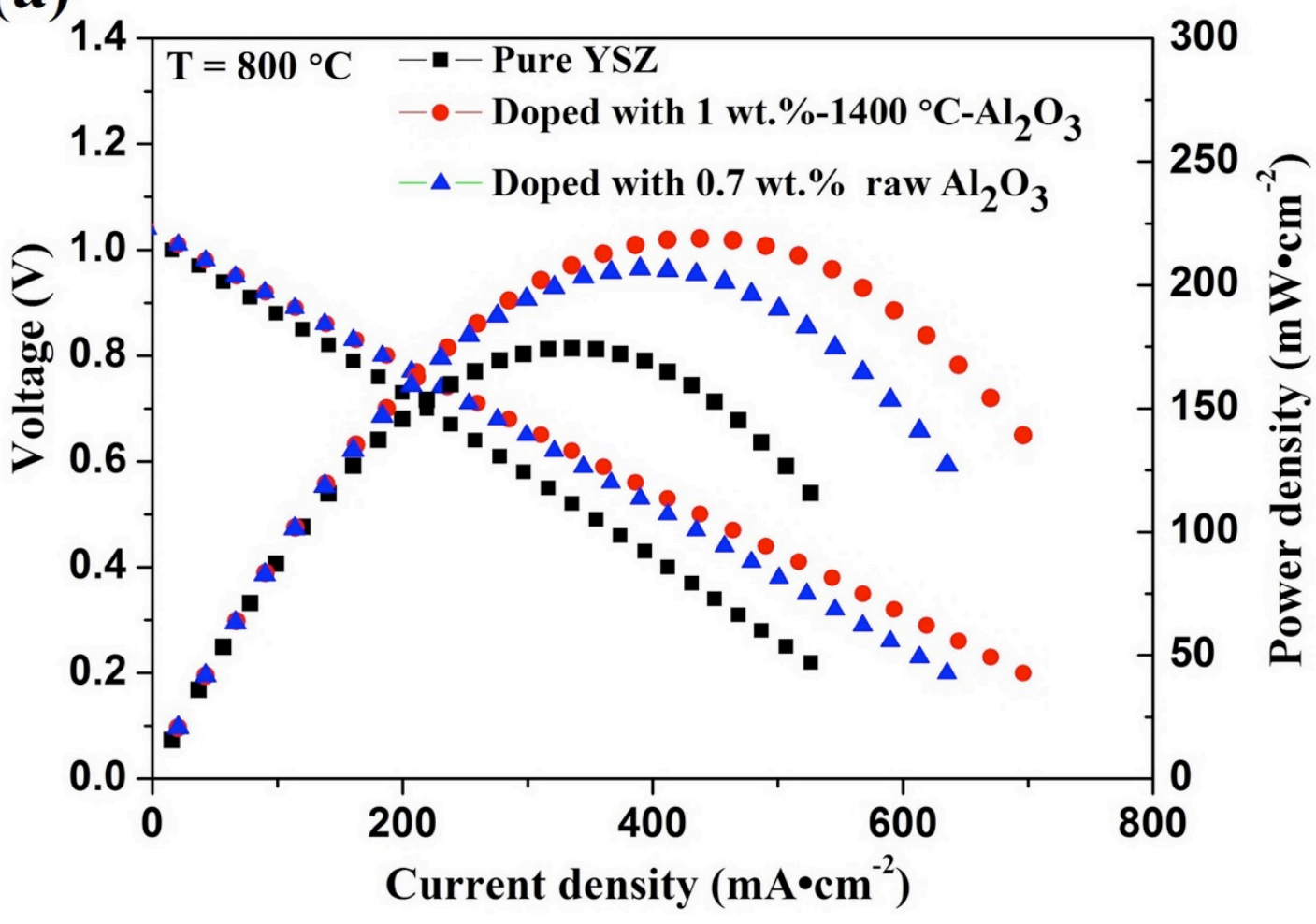

(b)

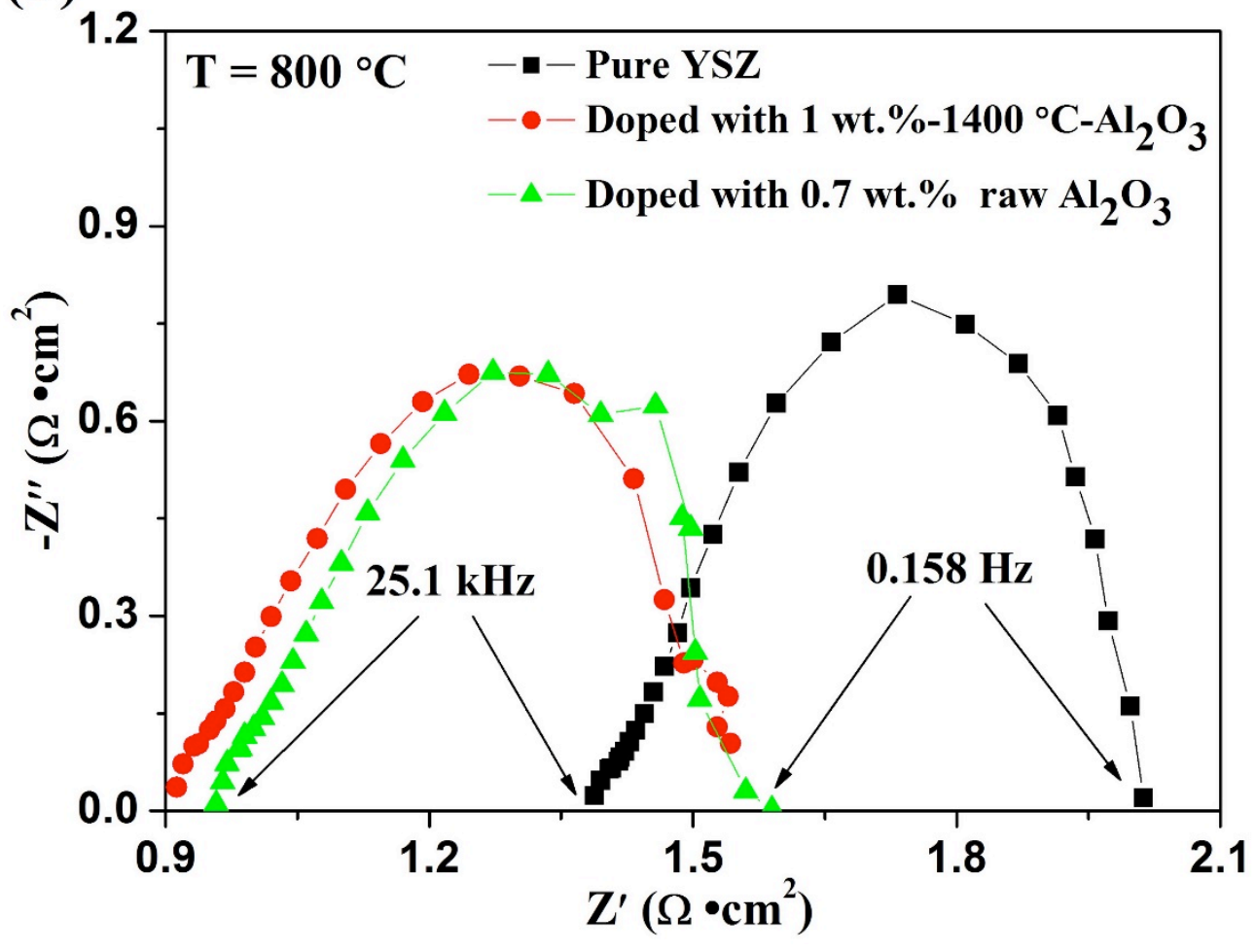

Fig. 7 


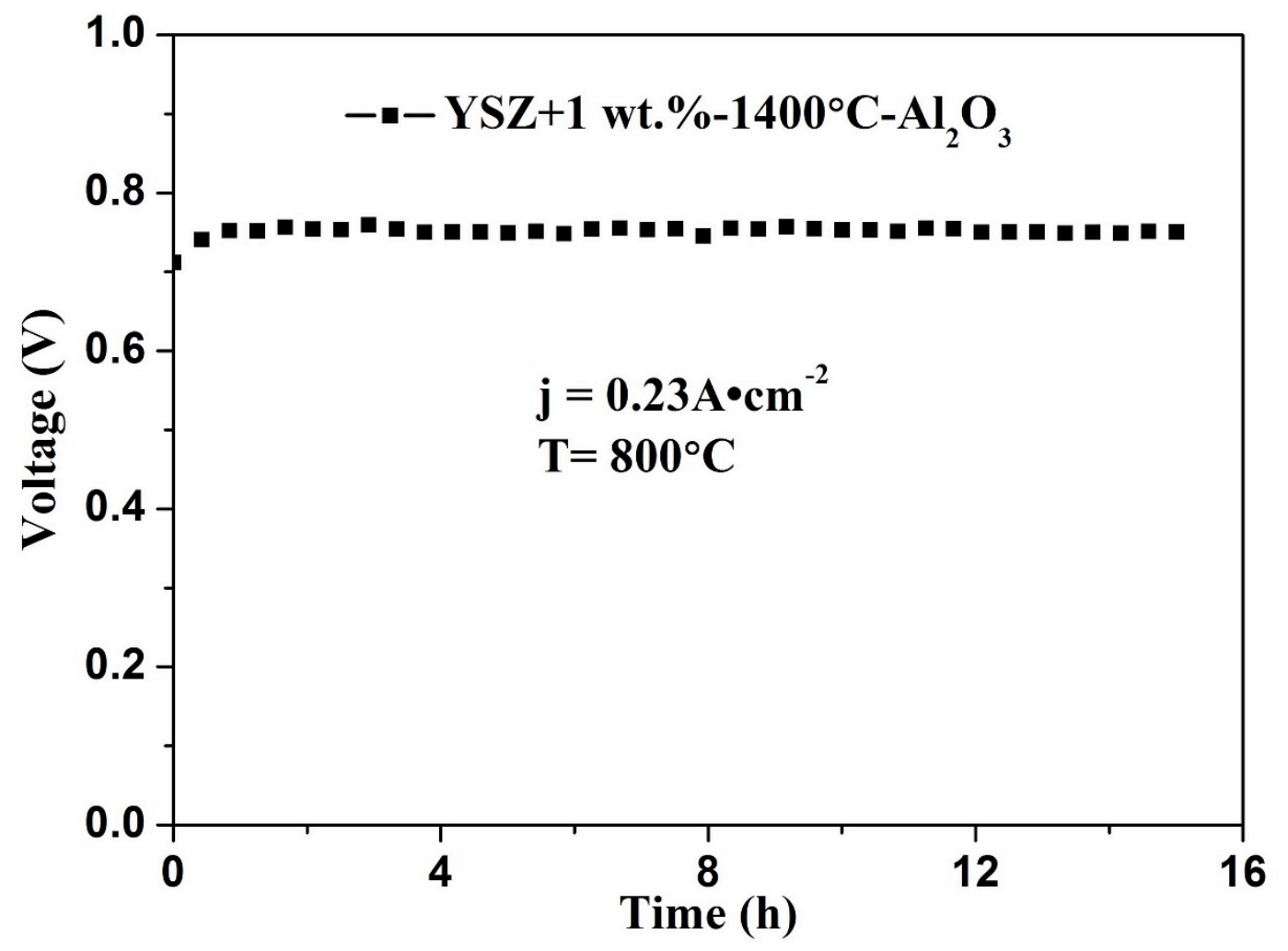

Fig. 8 